\title{
KESESUAIAN PENYUSUNAN LAPORAN KEUANGAN DESA TAHUN ANGGARAN 2015 PADA KANTOR DESA BHUANA GIRI DENGAN PERATURAN BUPATI KARANGASEM NOMOR 32 TAHUN 2015
}

\author{
Ni Luh Sri Wahyuni \\ Jurusan Pendidikan Ekonomi, Fakultas Ekonomi \\ Universitas Pendidikan Ganesha Singaraja, \\ Indonesia \\ e-mail : sri.wahyuni.sw109@gmail.com
}

\begin{abstract}
Abstrak
Penelitian ini bertujuan untuk mengetahui proses penyusunan laporan keuangan, kesesuaian pelaksanaan penyusunan laporan keuangan, kendala yang dihadapi dan cara mengatasi kendala dalam melakukan penyusunan laporan keuangan dengan Peraturan Bupati Karangasem Nomor 32 Tahun 2015. Jenis penelitian ini adalah penelitian deskriptif. Data diperoleh dengan melakukan wawancara dan dokumentasi. Metode analisis data yang digunakan adalah metode analisis deskriptif komparatif, yaitu dengan membandingkan antara penyusunan laporan keuangan Kantor Desa Bhuana Giri tahun anggaran 2015 dengan Peraturan Bupati Karangasem No 32 Tahun 2015 tentang Pengelolaan Keuangan Desa. Hasil penelitian ini menunjukkan bahwa, laporan keuangan yang disusun belum sepenuhnya lengkap, laporan keuangan Kantor Desa Bhuana Giri belum sepenuhnya menerapkan Peraturan Bupati Karangasem No 32 Tahun 2015 tentang Pengelolaan Keuangan Desa, terdapat kendala dalam sumber daya manusia, kualitas sumber daya manusia yang terlibat dalam penyusunan laporan keuangan lebih ditingkatkan dengan memberikan pendidikan maupun pelatihan atas aturan baru maupun aturan lama terkait dengan penyusunan laporan keuangan desa.
\end{abstract}

Kata kunci : laporan keuangan desa

This study aims to determine the process financial, the suitability of financial reporting, constraints and how to overcome abstacles in the preparation of financial statements with Regulation Karangasem Regent number 32 year 2015. This research type is descriptive research. Data were obtained by interview and documentation. Data analysis method used is comparative descriptive analysis method that is by comparing between financial reporting of Bhuana Giri village office in budget year 2015 with regulation of Karangasem Regent number 32 year 2015 about management of village finance.The result of this research indicate that, financial statements prepared is not yet fully completed, the financial reporting of Bhuana Giri village office fully implements regulation of Karangasem Regent number 32 year 2015 on management of village finance, there are constraits in human resources, quality of human resources which is held in the preparation of financial statements is further enchanced by providing education and training on new rules and old rules related to the preparation of village financial report.

Keyword: village financial statements

\section{PENDAHULUAN}

Di era reformasi pengelolaan keuangan daerah sudah mengalami beberapa perubahan regulasi dari waktu ke waktu. Perubahan tersebut merupakan rangkaian bagaimana suatu pemerintah daerah dapat menciptakan good governance dan clean government dengan melakukan tata kelola pemerintahan dengan baik. Keberhasilan dari suatu pembangunan di daerah tidak terlepas dari aspek pengelolaan keuangan daerah yang dikelola dengan manajemen yang baik pula.

Pengelolaan keuangan merupakan salah satu kegiatan administrasi yang sangat penting dalam ke 
pemerintahannya. Untuk menjamin akuntabilitas pengelolaan keuangan perlu diterapkan prinsip tata kelola yang baik. Selain itu, setiap organisasi seharusnya melakukan pelaksanaan anggaran dengan baik dan benar agar setiap kegiatan dapat dipertanggungjawabkan secara transparan. Menurut Peraturan Bupati Karangasem Nomor 32 Tahun 2015 tentang, "Pengelolaan Keuangan Desa adalah keseluruhan kegiatan yang meliputi perencanaan, pelaksanaan, penatausahaan, pelaporan, dan pertanggungjawaban keuangan desa."

Semakin baik pengelolaannya maka semakin baik pula manfaat dan hasil yang diperoleh masyarakat desa dalam kemajuannya, begitupun sebaliknya apabila pengelolaannya kurang memadai maka dana desa akan menimbulkan masalah dan dapat merugikan masyarakat desa. Dalam pengelolaan desa perlu memperhatikan kondisi dan kebutuhan dari masingmasing desa. Dengan demikian, diperlukan pengelolaan keuangan yang efektif dan efisien demi tercapainya tujuan desa yang optimal.

Menurut Peraturan Menteri Dalam Negeri No 113 Tahun 2014 desa adalah desa dan desa adat atau yang disebut dengan nama lain, selanjutnya disebut desa, adalah kesatuan masyarakat hukum yang memiliki batas wilayah yang berwenang untuk mengatur dan mengurus urusan pemerintah, kepentingan masyarakat setempat berdasarkan prakarsa masyarakat, hak asal usul, dan/atau hak tradisional yang diakui dan dihormati dalam sistem pemerintah

Didalam pemerintahan desa, kepala desa di Bali yang disebut dengan perbekel dibantu perangkat desa sebagai unsur dari penyelenggaraan desa. Menurut Ikatan Akuntansi Indonesia (2015) prinsip akuntansi adalah sebuah nilai-nilai yang dijadikan panutan dan dipatuhi oleh pembuat standar akuntansi. Dalam pengeloaan keuangan desa harus menjunjung tinggi prinsip-prinsip akuntabilitas. Menurut Mardiasmo
(2015) akuntabilitas publik adalah kewajiban pihak pemegang amanah untuk memberikan pertanggungjawaban, menyajikan dan mengungkapkan segala aktifitas dan kegiatan yang menjadi pertanggungjawaban kepada pihak pemberi amanah (principal) yang memiliki hak dan kewenangan untuk meminta pertanggungjawaban tersebut. Menurut Sabeni dan Imam (2001) akuntabilitas atau pertanggungjawaban (accountability) merupakan suatu bentuk keharusan seseorang (pimpinan/pejabat) untuk menjamin bahwa tugas dan kewajiban yang di embannya sudah dilaksanakan sesuai ketentuan yang berlaku.

Dalam upaya mewujudkan pemerintahan yang transparansi, menurut Nordiawan (2006) transparan memberikan informasi keuangan yang terbuka dan jujur kepada masyarakat berdasarkan pertimbangan bahwa masyarakat memiliki hak untuk mengetahui secara terbuka dan menyeluruh atas pertanggungjawaban pemerintah dalam pengelolaan sumber daya yang dipercayakan kepadanya dan ketaatanya pada peraturan perundang-undangan, dan partisipatif dibutuhkan adanya satu jaminan bahwa segala aktivitas dan transaksi pemerintah terekam secara baik dengan ukuran-ukuran yang jelas dapat diikhtisarkan melalui proses akuntansi dalam bentuk laporan, sehingga bisa dilihat segala yang terjadi dan terdapat di dalam ruang entitas pemerintahan tersebut. Sebagai upaya untuk mewujudkan transparansi, akuntabel, dan partisipatif pengelolaan keuangan desa di dalam penyampaian laporan pertanggungjawaban keuangan pemerintah yang memenuhi prinsip disiplin, tertib, taat pada peraturan perundang-undangan, efektif, efisien, ekonomis, transparan, dan bertanggungjawab dengan memperhatikan azas keadilan, kepatutan, dan manfaat untuk masyarakat. Proses pembuatan informasi keuangan berasal dari pencatatan bukti-bukti transaksi. 
Pencatatan bukti transaksi merupakan proses yang sangat penting dan berpengaruh pada proses penyususan laporan keuangan. Jika terjadi kesalahan pada penulisan bukti-bukti transaksi, maka laporan keuangan yang dihasilkan tidak akan valid dan relevan, dan tentunya akan menyesatkan atau mempersulit pengguna informasi keuangan tersebut.

Anggaran Pendapatan Belanja Desa (APBDesa) merupakan rencana keuangan tahunan yang dibahas dan disetujui bersama dengan pemerintah desa. APBDesa disusun sesuai dengan kebutuhan penyelenggaraan pemerintahan desa dan kemampuan pendapatan desa. Kedudukan APBDesa sangatlah penting sebagai alat untuk memelihara dan mengupayakan keseimbangan fundamental perekonomian daerah dalam proses pembangunan di daerah dan sebagai wadah untuk menampung berbagai kepentingan publik yang diwujudkan melalui program dan kegiatan. Proses penganggaran yang telah direncanakan dengan baik dan dilaksanakan dengan tertib serta disiplin akan mencapai sasaran yang lebih optimal. Pemerintah desa dalam menentukan kebijakan dan arah pembangunan yang mengutamakan potensi serta keunggulan desa sesuai dengan karakteristik desa sehingga APBDesa yang dihasilkan dapat memenuhi keinginan.

Laporan keuangan disusun untuk menyediakan informasi yang relevan mengenai posisi keuangan dan seluruh transaksi yang dilakukan oleh suatu entitas pelaporan selama satu periode pelaporan. Laporan keuangan terutama digunakan untuk membandingkan realisasi pendapatan, belanja, transfer, dan pembiayaan dengan anggaran yang telah ditetapkan, menilai kondisi keuangan, mengevaluasi efektivitas dan efisiensi suatu entitas pelaporan, dan membantu menentukan ketaatannya terhadap peraturan perundangundangan yang digunakan. Menurut Harahap (2009:10) "laporan keuangan menggambarkan kondisi keuangan dan hasil usaha suatu perusahaan pada saat tertentu atau jangka waktu tertentu". Menurut Kamaludin dan Indriani (2012) laporan keuangan adalah hasil akhir dari suatu proses pencatatan yang merupakan suatu ringkasan dari transaksi keuangan yang terjadi selama tahun buku yang bersangkutan. Dapat disimpulkan bahwa, laporan keuangan merupakan suatu proses pelaporan dan pertanggungjawaban keuangan yang menggambarkan kondisi keuangan pada saat tertentu atau selama tahun buku yang bersangkutan.

Penyajian laporan keuangan menjadi salah satu bentuk pertanggungjawaban secara tertulis atas kinerja keuangan yang telah tercapai. Penyajian laporan keuangan merupakan salah satu bentuk pelaksanaan akuntabilitas keuangan publik yang menjadi pertanggungjawaban bagaimana aparat desa dalam bentuk laporan keuangan. Pertanggungjawaban pelaporan keuangan yang baik dan benar akan mengurangi dan menghindarkan dari adanya penyelewengan atau pelanggaran-pelanggaran yang dilakukan oleh pemerintah seperti, korupsi, kolusi, dan nepotisme. Namun, tidak banyak desa yang sudah menerapkan ataupun membuat pembukuan laporan keuangan yang baik dan benar. Hal ini menyebabkan kepala desa maupun aparatur desa perlu paham benar bagaimana pembukuan di dalam pelaporan keuangan yang benar.

Penyajian laporan keuangan tidak terlepas dari orang-orang yang terlibat dalam penyajian laporan keuangan tersebut diantaranya: Pertama sumber daya manusia. Menurut Nawawi (2001:37) "sumber daya manusia adalah orang yang bekerja atau menjadi anggota suatu organisasi yang disebut personil, pegawai, tenaga kerja, dan lain-lain". Menurut Susilo (2002:3) "sumber daya manusia adalah pilar penyangga utama sekaligus penggerak organisasi dalam usaha mewujudkan visi, misi, dan tujuannya". 


\begin{abstract}
Dalam penyusunan dan pencatatan laporan keuangan dibutuhkan tenaga sumber daya manusia atau pegawai untuk menjalankan perangkat pendukung yang dipergunakan dalam penyusunan dan penyajian laporan keuangan. Sehubungan dengan Peraturan Bupati Karangasem Nomor 32 tahun 2015 dimana harus mengusai aplikasi komputer dalam menyusun dan menyajikan laporan keuangan, untuk itu sangat dibutuhkan pegawai yang mengerti dengan baik dan dapat menjalankan secara benar program aplikasi komputer.
\end{abstract}

Kedua perangkat pendukung. Perangkat pendukung yang dibutuhkan dalam penyusunan dan penyajian laporan keuangan adalah perangkat pendukung teknis. Perangkat pendukung teknis adalah perangkat keras (hardware) berupa unit komputer. Menurut Kemeth dan Jane (2005:18) "perangkat keras adalah perlengkapan fisik yang digunakan untuk aktifitas input, pemrosesan, dan output dalam sebuah sistem informasi". Dimana kumpulan perintah yang ditulis dalam bahasa-bahasa pemrograman yang kemudian akan diubah lagi menjadi bahasa mesin yang lebih rendah dan hanya dapat dimengerti oleh mesin

Sedangkan perangkat lunak (software) merupakan komponen kumputer yang berfungsi untuk mengatur hardware yang berupa susunan perintah/intruksi yang diberikan. Perangkat lunak (software) yang digunakan adalah aplikasi yang setidaknya bisa mengoperasikan program Microsoft Excel, karena dengan program ini mempermudah untuk menghitung secara otomatis untuk menyiapkan laporan keuangan desa ketika laporan tersebut dibutuhkan.

Penyusunan laporan keuangan Desa Bhuana Giri Kecamatan Bebandem Kabupaten Karangasem dilatar belakangi oleh Peraturan Bupati Karangasem Nomor 32 Tahun 2015 Tentang Pengelolaan Keuangan Desa. Peraturan Bupati Karangasem ini bahwa untuk melaksanakan ketentuan Pasal 43 Peraturan Menteri Dalam Negeri Nomor 113 Tahun 2014 tentang Pengelolaan Keuangan Desa, perlu menetapkan Peraturan Bupati tentang Pengelolaan Keuangan Desa. Peraturan Bupati tersebut juga merupakan salah satu komitmen besar untuk mendorong perluasan kesejahteraan bagi seluruh masyarakat. Peraturan ini juga mengatur materi sesuai pasal mengenai asas pengelolaan keuangan desa, kekuasaan pengelolaan keuangan desa, APBDesa, pendapatan, belanja desa, pengelolaan, pelaksanaan, penatausahaan, pelaporan, pertanggungjawaban, pembinaan dan pengawasan. Peraturan Bupati ini dibuat dengan tujuan agar setiap orang mengetahuinya, memerintahkannya pengundangan Peraturan Bupati ini dengan penempatannya dalam berita daerah Kabupaten Karangasem.

Peraturan Bupati tersebut menyebutkan bahwa setiap desa wajib membuat laporan keuangan yang lengkap, yang terdiri dari : pertama, Rancangan Peraturan Desa tentang APBdesa, kedua, Rancangan Anggaran Biaya, ketiga, Buku Kas Pembantu Kegiatan, keempat, Surat Permintaan Pembayaran, kelima, Pernyataan Tanggungjawab Belanja, keenam, Bukti Transaksi, ketujuh, Penatausahaan, kedelapan, Laporan Realisasi Pelaksanaan APBDesa Semester, serta kesembilan, Laporan Pertanggungjawaban Realisasi Pelaksanaan APBDesa, namun kenyataannya Kantor Desa Bhuana Giri tidak membuat pelaksanaan laporan keuangan yang lengkap sesuai pedoman peraturan Bupati Karangasem Nomor 32 Tahun 2015 Tentang Pengelolaan Keuangan Desa yang digunakan, dimana kantor desa ini kurang melampirkan laporan kekayaan milik desa, serta dalam pembuatan laporan pertanggungjawaban di masingmasing kegiatan lampiran bukti transaksi masih ada yang kurang dilampirkan. Dari permasalahan tersebut, maka penulis tertarik untuk 
melakukan penelitian tentang "Kesesuaian Penyusunan Laporan Keuangan Desa Tahun Anggaran 2015 Pada Kantor Desa Bhuana Giri Dengan Peraturan Bupati Karangasem Nomor 32 Tahun 2015"

Penelitian ini bertujuan untuk, mengetahui tentang penyusunan laporan keuangan pada Kantor Desa Bhuana Giri tahun anggaran 2015, meneliti dan memberikan informasi tentang kebenaran dalam pelaksanaan penyusunan laporan keuangan desa tahun anggaran 2015 sesuai dengan Peraturan Bupati Karangasem Nomor 32 Tahun 2015, mengetahui kendala yang dihadapi oleh Kantor Desa Bhuana Giri, dan mengetahui cara untuk mengatasi kendala dalam melakukan penyesuaian penyusunan laporan keuangan desa tahun anggaran 2015 tersebut.

\section{METODE}

Penelitian ini merupakan penelitian deskriptif. Menurut Narbuko dan Chamadi (2009:44) penelitian deskriptif merupakan penelitian yang berusaha untuk menuturkan pemecahan masalah yang ada sekarang berdasarkan data-data, penelitian ini juga menyajikan data, menganalisis dan menginterprestasi. Sumber data penelitian ini yaitu data primer terdiri dari hasil wawancara berupa tanya jawab langsung dengan bendahara desa dan sekretaris desa, dan data sekunder yaitu berupa laporan keuangan Kantor Desa Bhuana Giri. Subyek yang dijadikan unit pengamatan dalam penelitian ini adalah sub bidang keuangan desa dan sekeretaris desa. Sedangkan yang menjadi obyek penelitian adalah laporan keuangan Kantor Desa Bhuana Giri tahun anggaran 2015 yang telah disusun.

Teknik pengumpulan data dalam penelitian ini yaitu wawancara, dan dokumetasi. Metode analisis data yang digunakan dalam penelitian ini adalah peneliti akan menggunakan teknik deskriptif komparatif, yaitu dengan membandingkan antara penyusunan laporan keuangan Kantor Desa Bhuana
Giri Tahun 2015 dengan Peraturan Bupati Karangasem Nomor 32 Tahun 2015 tentang Pengelolaan Keuangan Desa, tujuannya adalah untuk mengetahui kesesuaian dan ketidaksesuaian penyusunan laporan keuangan Kantor Desa Bhuana Giri anggaran 2015 dengan Peraturan Bupati Karangasem Nomor 32 Tahun 2015 Tentang Pengelolaan Keuangan Desa.

\section{HASIL DAN PEMB AHASAN Hasil}

Menurut Peraturan Bupati Karangasem Nomor 32 Tahun 2015 Tentang Pengelolaan Keuangan Desa. Pengelolaan Keuangan Desa adalah keseluruhan kegiatan yang meliputi dari perencanaan, pelaksanaan, penatausahaan, pelaporan, pertanggungjawaban, tentu saja peraturan tersebut harus dilaksanakan disetiap desa yang ada di daerah administratif Kabupaten Karangasem. Penyusunan laporan keuangan dimulai dari proses perencanaan. Menyusun Rencana Kerja Pemerintah Desa (RKPDesa). Rancangan peraturan desa tentang RKPDesa disusun oleh sekretaris desa, berdasarkan RKPDesa yang nantinya menjadi dasar penyusunan APBDesa.

Laporan keuangan Desa Bhuana Giri ditahap pelaksanaan terdiri dari pembuatan rancangan anggaran biaya yang dibuat dalam bentuk lembar kerja APBDesa. Lembar kerja akan diverifikasi oleh sekretaris desa dan disahkan oleh kepala desa, kemudian pelaksana kegiatan bertanggungjawab terhadap tindakan pengeluaran dengan membuat buku kas pembantu kegiatan.

Dalam pelaksana kegiatan jika melakukan pemesanan barang harus mengajukan surat permintaan pembayaran. Surat permintaan pembayaran yang telah diverifikasi oleh sekretaris desa akan disetujui oleh kepala desa dan bendahara desa akan melakukan pembayaran. Pembayaran yang telah dilakukan akan dicatat oleh bendahara desa, bendahara desa wajib melakukan pencatatan setiap 
penerimaan dan pengeluaran serta melakukan tutup buku setiap akhir bulan secara tertib. Penerimaan dan pengeluaran dalam bentuk penatausahaan dilakukan oleh bendahara desa dalam bentuk buku kas umum, buku kas pembantu pajak, dan buku bank desa.

Setelah tahap penatausahaan dilanjutkan ke tahap pelaporan. Laporan realisasi pelaksanaan APBDesa akan disampaikan oleh kepala desa kepada bupati berupa laporan semester pertama dan laporan semester akhir tahun. Dalam laporan pertanggungjawaban realisasi pelaksanaan APBDesa akan disampaikan secara periodik oleh kepala desa kepada bupati setiap akhir tahun anggaran.

Dalam penyusunan laporan keuangan Desa Bhuana Giri terdapat kendala di dalam penerapannya. Kendala pertama yang dihadapi Kantor Desa Bhuana Giri adalah sumber daya manusia, terdapat pegawai yang masih kurang didalam bidang pendidikan maupun pelatihan khususnya bidang akuntansi. Adapun kendala lainnya yang dihadapi adalah setiap pengambilan maupun pengeluaran uang tidak sesuai dengan sistem.

\section{Pembahasan}

Berdasarkan hasil penelitian, dapat dijelaskan bahwa pertama, laporan keuangan Desa Bhuana Giri tahun anggaran 2015 di dalam penyusunannya belum sepenuhnya menerapkan Peraturan Bupati Karangasem Nomor 32 Tahun 2015 Tentang Pengelolaan Keuangan Desa. Ini dikarenakan peraturan tersebut disahkan pada pertengahan tahun yaitu pada tanggal 6 Juli 2015. Hal ini belum sesuai dengan Peraturan Bupati Karangasem Nomor 32 Tahun 2015 Tentang Pengelolaan Keuangan Desa yang menyatakan, penyusunan laporan keuangan disusun berdasarkan tahap yang ditetapkan di Peratuan Bupati Karangasem Nomor 32 yang dimulai dari tahap perencanaan yang membuat rancangan peraturan desa tentang
APBDesa, kemudian di tahap pelaksanaan yang membuat rancangan anggaran biaya yang diverifikasi oleh sekretaris desa dan di sahkan oleh kepala desa, setiap pelaksana kegiatan jika melakukan pemesanan barang harus mengajukan surat permintaan pembayaran yang disertai dengan pernyataan tanggungjawab belanja dan bukti transaksi yang lengkap.

Pada tahap penatausahaan laporan keuangan yang dibuat untuk mencatat setiap penerimaan dan pengeluaran menggunakan buku kas umum, buku kas pembantu pajak, dan buku bank desa. Kemudian pada tahap pelaporan kantor desa membuat laporan semester pertama yang disampaikan paling lambat pada akhir bulan Juli dan laporan semester akhir tahun yang disampaikan pada akhir bulan Januari. Pada tahap pertanggungjawaban laporan keuangan yang disusun yaitu, laporan pertanggungjawaban realisasi pelaksanaan APBDesa setiap akhir tahun anggaran yang ditetapkan dengan peraturan desa dan melampirkan laporan kekayaan milik desa per 31 Desember dan laporan program pemerintah dan pemerintah daerah yang masuk ke desa.

Kedua, laporan keuangan yang tidak sesuai pada tahun anggaran 2015 terdapat pada format pembuatan rancangan peraturan desa tentang APBDesa, format penyajian rancangan anggaran biaya, format pembuatan buku kas umum, format pembuatan buku kas pembantu pajak, format laporan semester pertama dan akhir, periode pelaporan, dan format pembuatan laporan pertanggungjawaban realisasi pelaksanaan APBDesa yang tidak sepenuhnya sesuai, dalam Peraturan Bupati Karangasem Nomor 32 Tahun 2015. Adapun laporan keuangan yang dimaksud yaitu: pertama, rancangan peraturan desa tentang APBDesa. Di dalam tahap perencanaan yang membuat rancangan peraturan desa tentang APBDesa dibuat sebagai dasar penyusunan APBDesa, rancangan 
peraturan desa meliputi SK peraturan desa yang didalamnya terdapat pendapatan, belanja desa, dan pembiayaan desa selama satu periode atau satu tahun.

Dalam format pembuatan belum sesuai dengan acuan Peraturan Bupati Karangasem Nomor 32 Tahun 2015 yang terdiri dari 4 kolom dengan nama kolom kode rekening, uraian, anggaran, dan keterangan. Rancangan peraturan desa tentang APBDesa yang dibuat oleh Kantor Desa Bhuana Giri terdiri dari 4 kolom dengan nama kolom kode rekening, uraian, sebelum perubahan, setelah perubahan, dan bertambah/berkurang. $\mathrm{Hal} \mathrm{ini}$ dikarenakan rancangan peraturan desa yang dibuat masih menggunakan aturan lama dan baru menyesuaikan dengan aturan yang baru. Sedangkan untuk pendapatan, belanja desa, dan pembiayaan komponenya sudah sesuai dengan aturan yang baru. Kedua, rancangan anggaran biaya, menjadi dasar bagi pelaksanaan kegiatan untuk melakukan tindakan pengeluaran atas beban anggaran belanja kegiatan.

Rancangan anggaran biaya meliputi bidang yang diisi dengan kode rekening berdasarkan klasifikasi kelompok belanja desa, kegiatan, dan waktu pelaksanaan. Dalam format kolom pembuatan sudah sesuai dengan acuan Peraturan Bupati Karangasem Nomor 32 Tahun 2015. Akan tetapi rancangan anggaran biaya yang dibuat oleh Kantor Desa Bhuana Giri dalam bentuk lembar kerja. Jika hal ini terus berlanjut, maka nantinya akan terdapat permasalahan dalam pembuatan laporan keuangan selanjutnya.

Ketiga, buku kas umum. Buku kas umum digunakan untuk mencatat transaksi yang bersifat tunai, yang pencatatanya dilakukan secara kronologis. Buku kas umum terdiri dari 9 kolom dengan nama kolom no, tanggal, kode rekening, uraian, penerimaan, pengeluaran, nomor bukti, jumlah pengeluaran komulatif, dan saldo.

Dalam format pembuatan belum sesuai dengan acuan Peraturan Bupati Karangasem Nomor 32 Tahun 2015.
Format buku kas umum yang dibuat oleh Kantor Desa Bhuana Giri terdiri dari 6 kolom dengan nama kolom nomor urut, tanggal, nomor rekening, uraian, penerimaan, dan pengeluaran. Jika hal ini terus berlanjut, maka nantinya akan terdapat permasalahan dalam pembuatan laporan keuangan, ini dikarenakan masih menggunakan aturan yang lama dan baru menyesuaikan dengan aturan yang baru. Keempat, buku kas pembantu pajak. Buku kas pembantu pajak digunakan untuk mencatat pungutan/potongan yang dilakukan oleh bendahara desa. Buku kas pembantu pajak terdiri dari 6 kolom dengan nama kolom no, tanggal, uraian, pemotongan, penyetoran, dan saldo.

Dalam format pembuatan belum sesuai dengan acuan Peraturan Bupati Karangasem Nomor 32 Tahun 2015. Format buku kas pembantu pajak yang dibuat oleh Kantor Desa Bhuana Giri terdiri dari 5 kolom dengan nama kolom no, tanggal, uraian, pemotongan, penyetoran. Jika ini terus berlanjut, maka nantinya tidak akan mengetahui sisa saldo akhirnya untuk pembuatan laporan keuangan berikutnya. Ini dikarenakan masih menggunakan aturan yang lama dan baru menyesuaikan dengan aturan yang baru.

Kelima, laporan semester pertama dan laporan semester akhir tahun. Laporan semester pertama dan laporan semester akhir tahun adalah laporan yang dibuat per 6 bulan. Dalam format kolom pembuatan sudah sesuai dengan acuan Peraturan Bupati Karangasem Nomor 32 Tahun 2015. Akan tetapi untuk periode pelaporannya berbeda dengan peraturan yang baru karena masih menggunakan aturan lama dan baru menyesuaikan dengan aturan yang baru yang periode pelaporannya untuk laporan semester pertama disampaikan selambat-lambatnya pada akhir bulan Juli tahun berjalan dan laporan semester akhir tahun disampaikan pada akhir bulan Januari. Jika terus berlanjut, maka akan terjadi permasalahan keterlambatan 
mengumpulan laporan keuangan ke pemerintah daerah

Keenam,

laporan

pertanggungjawaban

realisasi

pelaksanaan APBDesa. Laporan

pertanggungjawaban realisasi

pelaksanaan APBDesa adalah laporan

keuangan tahunan pemerintah desa.

Laporan pertanggungjawaban realisasi pelaksanaan APBDesa meliputi pendapatan desa, belanja desa, dan pembiayaan desa selama satu periode atau satu tahun. Dalam pembuatan belum sesuai dengan acuan Peraturan Bupati Karangasem Nomor 32 Tahun 2015 yang SK rancangan peraturan desanya dipisahkan dari laporan realisasi pelaksanaan APBDesa. Laporan realisasi pelaksanaan APBDesa juga belum melampirkan laporan kekayaan milik desa, laporan program pemerintah dan program daerah yang masuk desa, serta periode pelaporan yang berbeda. Jika ini terus berlanjut, maka nantinya akan terdapat permasalahan dalam pembuatan laporan keuangan. Ini juga dikarenakan masih menggunakan aturan yang lama dan baru menyesuaikan dengan aturan yang baru.

Ketiga terdapat kendala didalam penyusunan laporan keuangan yaitu adanya keterbatasan dari sumber daya manusia di dalam hal pendidikan, kurangnya pelatihan, maupun sosialisasi yang menghambat dalam proses penyusunan laporan keuangan Desa Bhuana Giri sesuai Peraturan Bupati Karangasem Nomor 32 Tahun 2015 dan kendala lainnya yaitu di dalam pengeluaran uang masih tidak dilakukan secara sistem ataupun secara bertahap.

Cara yang bisa dilakukan Kantor Desa Bhuana Giri agar penyusunan laporan keuangan bisa dilaksankan dengan baik adalah sebagai berikut. Pertama, dengan suatu pelatihan yang dilaksanakan dapat memberikan penekanan pada tugas yang harus dilaksanakan oleh pegawai, selain pelatihan juga menekankan kepada kemampuan keterampilan dan sikap pegawai.
Menurut Notoatmojo (2009:16) pelatihan merupakan upaya yang berkaitan dengan peningkatan kemampuan atau keterampilan pegawai yang sudah menduduki suatu pekerjaan atau tugas tertentu. Jadi dengan adanya pelatihan, kemampuan dan keterampilan pegawai lebih meningkat, sehingga jika terdapat perubahan aturan lama ke aturan baru, tidak terjadi kesalahan di dalam penyusunan laporan keuangan. Kedua, setiap melakukan pengeluaran uang pihak kantor desa lebih memperketat atau menerapkan prinsip disiplin anggaran dalam melakukan kegiatan. Dalam hal ini menurut pendapat Nordiawan (2007) disiplin anggaran merupakan penganggaran pengeluaran harus didukung dengan adanya kepastian tersedianya penerimaan dalam jumlah yang cukup dan tidak dibenarkan melaksanakan kegiatan atau proyek yang belum atau tidak tersedia anggarannya. Dengan kata lain, bahwa penggunaan setiap pos anggaran harus sesuai dengan kegiatan atau proyek yang diusulkan.

\section{SIMPULAN DAN SARAN Simpulan}

Adapun simpulan dari penelitian ini adalah laporan keuangan yang disusun oleh Kantor Desa Bhuana Giri pada tahun anggaran 2015 yang dibuat mulai dari tahap perencanaan, pelaksanaan, penatausahaan, pelaporan, dan pertanggungjawaban, belum sepenuhnya dibuat dengan lengkap. Laporan keuangan yang dibuat yaitu: pada tahap perencanaan Kantor Desa Bhuana Giri membuat rancangan peraturan desa tentang APBdesa, tahap pelaksanaan membuat laporan lembar kerja, buku kas pembantu kegiatan, surat permintaan pembayaran, dan lampiran bukti transaksi. Tahap selanjutnya yaitu, penatausahaan pada tahap ini Kantor Desa Bhuana Giri membuat buku kas umum, buku kas pembantu pajak, dan buku bank desa, kemudian pada tahap pelaporan yang membuat laporan semester pertama 
dan laporan semester akhir tahun, dan tahap pertanggungjawaban membuat laporan pertanggungjawaban realisasi pelaksanaan APBDesa.

Kedua pelaksanaan laporan keuangan yang disusun oleh Kantor Desa Bhuana Giri sudah mengacu pada Peraturan Bupati Karangasem Nomor 32 Tahun 2015, akan tapi masih banyak ketidaksesuain yang diterapkan pada lapangan, khususnya pada format pembuatan laporan keuangan rancangan peraturan desa tentang APBDesa, rancangan anggaran biaya yang dibuat dalam bentuk Laporan lembar kerja, format pembuatan buku kas umum, buku kas pembantu pajak, laporan semester pertama dan akhir tahun, serta format pembuatan laporan pertanggungjawaban realisasi pelaksanaan APBDesa yang laporan SK rancangan peraturan desa tentang APBDesa dipisahkan dan belum melampiran laporan kekayaan milik desa, laporan program pemerintah, dan program daerah yang masuk desa. Ketiga dalam penyusunan laporan keuangan Kantor Desa terdapat kendala di dalam sumber daya manusia yang masih belum mampu menyusun laporan keuangan. Kualitas sumber daya manusia, perubahan peraturan, pengeluaran uang yang tidak dilakukan secara sistem, serta kurangnya sosialisasi dari pihak kantor desa menjadi hambatan dalam penyusunan laporan keuangan di Kantor Desa Bhuana Giri.

\section{Saran}

Berdasarkan simpulan penelitian diatas, dapat dikemukakan beberapa saran sebagai berikut pertama, untuk tahun berikutnya Kantor Desa Bhuana Giri dalam penyusunan laporan keuangan yang mengacu pada Peraturan Bupati Karangasem Nomor 32 Tahun 2015, diharapkan agar disusun dan lengkapi secara lengkap, dalam rangka menciptakan laporan keuangan Kantor Desa Bhuana Giri yang baik (good governance). Kedua pada tahun anggaran selanjutnya Kantor Desa Bhuana Giri harus bisa menyesuaikan dengan benar penyusunan laporan keuangan yang berpedoman pada Peraturan Bupati Karangasem Nomor 32 Tahun 2015 khususnya pada format yang masih banyak kesalahan dalam penyusunanya.

Dengan adanya laporan keuangan yang sesuai dengan peraturan, dapat mempermudah untuk mengetahui adanya kecurangan dalam hal laporan keuangan. Sehingga diharapkan tidak terdapat kesalahan lagi dalam penyusunan laporan keuangan. Ketiga kualitas sumber daya manusia yang terlibat dalam penyusunan laporan keuangan lebih ditingkatkan dengan memberikan pendidikan maupun pelatihan atas aturan baru maupun aturan lama terkait dengan penyusunan laporan keuangan, setiap melakukan pengeluaran uang pihak kantor desa lebih memperketat atau menerapkan prinsip disiplin anggaran dalam melakukan kegiatan agar tidak terjadi kesalahan dibidang keuangan.

\section{DAFTAR PUSTAKA}

Anonim. Peraturan Bupati Karangasem Nomor 32 Tahun 2015. tentang Pengelolaan Keuangan Desa.

--------. Peraturan Menteri Dalam Negeri No. 113 Tahun 2014. tentang Pengelolaan Keuangan Desa.

Harahap, Sofyan Syafri. 2007. Teori Akuntansi. Jakarta: PT Raja Grafindo Persada.

Ikatan Akuntansi Indonesia. 2015. Standar Akuntansi Keuangan Desa. Jakarta: Salemba Empat

Kamaludin dan Rini Indriani. 2012. Manajemen Keuangan. Konsep Dasar dan Penerapannnya. Edisi Revisi. Bandung: CV Mandar Maju.

Kemeth dan Jane. 2005. Mengelola Perusahaan Digital. Yogyakarta: Penerbit Andi

Mardiasmo. 2002. Akuntansi Sektor Publik. Yogyakarta: Penerbit Andi

Narbuko, Cholid dan Abu A Chamadi. 
2010. Metode Penelitian. Jakarta: PT Bumi Aksara

Nawawi, Hadari. 2001. Perencanaan

Sumber Daya Manusi untuk Organisasi Profit yang Kompetitif. Yogyakarta: Gajah Mada University Press

Nordiawan, Deddi. 2006. Akuntansi

Sektor Publik. Yogyakarta:

ANDI OFFSET

Pokok-Pokok Akuntansi

Pemerintahan. Yogyakarta:

BPF

Notoatmodjo, Soekidjo. 2009.

Pengembangan Sumber Daya

Manusia. Jakarta: PT Rineka

Cipta

Sabeni, Arifin dan Ghozali Imam. 2001.

Pokok-Pokok Akuntansi

Pemerintahan. Yogyakarta:

BPF

Sujarweni, V. Wiratna, 2015. Akuntansi

Desa. Yogyakarta: Pustaka Baru Press

Susilo. 2002. Audit Sumber Daya Manusia. Jakarta: Penerbit Gema Amini 